Revista publicada por la Universidad de Concepción

\title{
COMISION DIRECTORA:
}

Enrique Molina, Samuel Zenteno A., Luis D. Cruz Ocampo, Salvador Gálvez y Abraham Valenzuela C. (Secretario). EDITOR Y AGENTE GENERAL: CARLOS JORGE NASCIMENTO

\begin{tabular}{lll}
\hline \hline AÑo I & JUNIO DE 1924 & NÚM. 3 \\
\hline \hline
\end{tabular}

Amanda Labarea $\mathbf{H}$.

\section{Meditaciones}

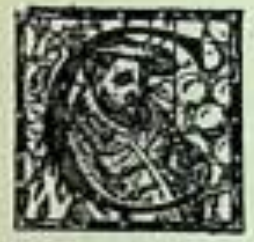

UANDO se reflexiona sobre la maravillosa arquitectura del pensamiento griego, célula de donde se ha desarrollado el pensamiento europeo de veinticinco siglos y se pregunta uno por qué sucumbió esa raza en plena juventud, se inclina a buscar la respuesta en su falta de sen-

tido mistico.

El pueblo heleno vivió lo que sus dioses. A Sócrates. Platón. Aristóteles, a los poetas como Esquilo, a los artistas como Fidias. la Filosofía y el Arte les salvaron de la Muerte. Mas, la gran masa de los atridas que no pudo elevarse a la visión de un ideal nuevo. superior a las divinidades tradicionales, fué incapaz de impregnar de inmortalidad la arcilla de su carne que se deshizo en polvo en las luchas fraIricidas.

No hay conciencia sin tragedia. No hay hombre inteligente que no se haya cerciorado con lágrimas que la dicha es engañosa, que a mayor capacidad para gozar corresponde una mayor potencia para sufrir. que hasta la copa de miel que nos brinda sonriente el amor ilusionado es un lazo que nos tiende el Dolor.

En este trance, el sentido místico o el hábito religioso colocan al frente de la realidad sensible una intuición ideal que transfigura el dolor de los hechos en esperanzas de futuros bienes. Y el hombre se consuela imaginando que su pena es fecunda. Abraza con nuevo vigor sus ilusiones. La vida triunfa.

Cosa semejante ocurre en la existencia colectiva de los pueblos. La fe en sus destinos superiores, la ilusión de ser una raza protegida de Dios. les dá un impulso espiritual supremo.

Mas, si ese sentido místico, esa transmutación constante de valores efimeros 
en valores eternos. de actos materiales en anhelos ideales falta, no podemos imaginar nuestra vida y nuestro yo sino en el plano de las cosas que nacen, viven y mueren como las flores del campo y las aves del cielo, es decir. sin finalidad racional ninguna.

Si aceptamos la no finalidad de la vida humana, si nos convencemos de que la Belleza. la Verdad y el Bien son valores relativos y perecederos, si creemos que nuestra vida es y será siempre imperfecla, dolorosa e inútil, no queda en pie sino una sola verdad: la Nada. Para quien la ha mirado cara a cara, para quien siente que la nada es el principio y el fin de la existencia, no hay vida posible. Aunque deambule por la tierra y hable, está muerlo, porque se quebraron ya en él las ilusiones vitales que permiten sobreponerse a la tragedia cuotidiana.

Este sentido místico faltó a los griegos como ha faltado después a la mayoria de sus hijos, los latinos, y nosotros los hispanos-américos. Porque hay diferencia entre la tendencia mistica y la aceptación de un credo. Se puede ser fanático sin ser en modo alguno un místico.

El instinto místico es una fuerza creadora, creadora de dioses, la religiosidad es un hábito pasivo capaz de extraer, incluso, supremas bellezas de un contenido ya dado. pero incapaz de crear nuevos símbolos.

Las razas europeas mediterráneas, desde el momento en que las conoce la historia, no han creado religiones; las han heredado de otros pueblos, adaptándolas a su idiosincracia mientras esas religiones fueron plásticas.

En tiempo de Aristófanes, los dioses griegos habrían perdido ya todo prestigio. ıCon qué ancha y sonora carcajada no se burla ese comediante inmortal de santuarios. de presagios y de oráculos! El hombre crea a sus dioses a su imagen y semejanza. Zeus. Apolo. Atenca y las vengadoras Erinias simbolizaban aspectos típicos del alma griega; pero mientras el hombre vivo evoluciona, el milo, consagrado por la religión, permanece inalterable. El dogma momifica el símbolo, y el sacerdote es el celoso guardiān en el sepulcro de los dioses muertos, hasta que llega un momento en que el hombre evolucionado mira al Zeus que engendraron sus antepasados como un mito inferior y le abandona.

Este momento de crisis, de crisis la más honda de la conciencia humana, es el instante decisivo en el destino de los pueblos. O aceptan éstos, normas de vida en que nuevos conceptos racionales reemplazan a las religiones, o ayudados de su espiritu místico, crean nuevos dioses.

Los griegos fueron incapaces de lo segundo. Su filosofia, a partir de Aristóteles es una filosofia de la razón. Epicuro les dió la más inteligentisima. la más perfecta. la más asombrosa explicación del Universo que era posible concebir dados los reducidos conocimientos de la época. Todo lo tuvo este divino super-hombre, menos el sentido místico. Tampoco lo poseyeron los estoicos a pesar de la bienaventurada mansedumbre de Marco Aurclio. Epicuros y estoicos fueron los positivistas de la decadencia antigua. Veinte y tantos siglos antes de Compte proclamaron ellos su religión de la humanidad y talvez nunca los conceptos modernos de la solidaridad humana, fueron más bellamente expresados que en las oraciones de Cicerón y en las epistolas de Séneca. 
A los ojos de la razón. los sistemas positivistas tienen que aparecer con una evidente superioridad intelectual y ética sobre los sistemas misticos. Requieren de quienes lo aceptan a conciencia, una gran dosis de reflexión y sabiduría. Para dominar las pasiones. para domeñar la férrea garra del egoísmo con la sola ayuda de la razón, el hombre necesita de un esfuerzo incesante de la voluntad. Resistir al mismo tiempo al placer y al dolor en nombre de un Bien ideal. sin aguardar recompensas futuras y sin otro norte que la paz secreta de la conciencia, ha menester de una superioridad ética admirable. IY si fuera sólo resistir a las pasiones! El hábito y el tiempo las doblegan. Pero hay también que soportar el dolor. la injusticia, el fracaso, el desengaño, la muerte. Se necesita más heroismo para sufrir con resignación que para apartar de sí la copa del néctar prohibido.

No obstante su superioridad intelectual y ética, estos sistemas racionalistas no han servido jamás para conducir a los pueblos a una vida más amplia y más feliz. $\mathrm{Ni}$ siquiera a los helenos, carne e inteligencia de dioses. El racionalismo ignora el instinto místico, el cual viene acompañando al hombre desde que le conoce la historia y que existe en él tan primariamente como cualquier otro de los instintos fundamentales. El instinto de saber, de darse cuenta del mundo. de comprender, ha dado origen a la filosofia y a la ciencia: el instinto místico ha creado las religiones. proporcionando al hombre otra forma de conocimiento que suple las deficiencias de su comprensión corta y de su saber escaso. Mientras las primeras hallaron su lenguaje en la experiencia real, la segunda se tradujo en símbolos.

Los grandes períodos de florecimiento humano son esos en que ambos instinlos se armonizan como las cuerdas de una misma lira. Los tiempos de decadencia. en cambio. son aquellos en que uno de esos instintos tiende a suprimir, a aniquilar al otro.

Para muchos hombres cultos de hoy la religión europea sustenta símbolos arcaicos. El Jehová implacable que juzga a los pecadores y les castiga a una condenación eterna, las llamas de los infiernos, el papel de los demonios, el soberano albedrio, son ofros tantos dogmas que muchos hombres modernos se resisten a aceptar. Y como no cultivaron jamás su instinto mistico y en cambio han sido educados en la superioridad de la ciencia positiva, desligándose fácilmente de la religión heredada, se hallan en medio de la vida en la incapacidad de adaplar los rezagados símbolos a sus nuevos ideales, ni de crear para ellos o para su pueblo una nueva religión. Ingresan desde ese instante a los sistemas racionalistas de vida.

El hombre necesita comprender. La razón es incapaz de darnos la respuesta de los por qué fundamentales. Necesita saber para qué sufre: a qué meta ha de llegar el mundo: cuál excelso o misero fin ha de ser el del Hombre sobre la Tierra. La ciencia ignora todo esto. La religión lo enseñó a los que fueron tocados por la gracia y la Fe. Mientras tanto, para los que dudan la interrogación es cada vez más honda. Como una llaga de fuego. llevamos en la frenle el signo del Por qué y del Para qué.

AMANDA LABARCA $\mathrm{H}$.

Concepción. Abril de 1924. 